\title{
TINGKAT PENDAPATAN, POLA KONSUMSI, DAN POLA MENABUNG PETANI GARAM DALAM PERSONAL FINANCE
}

\author{
Aprilina Susandini ${ }^{1}$ \\ Miftahul Jannah ${ }^{2}$ \\ ${ }^{1}$ Universitas Trunojoyo Madura, Indonesia \\ ${ }^{1}$ aprilina.susandini@trunojoyo.ac.id \\ ${ }^{2}$ Universitas Trunojoyo Madura, Indonesia \\ 2miftahul.jannah@trunojoyo.ac.id
}

\begin{abstract}
Personal finance is a financial management scope was used to manage finances from respective person. A good quality of life requires a good financial and a good financial can be achieved with proper financial planning. Financial management of personal occurs for salt farmers too who have income in seasonal. This study aims to describe Salt farmers Madura income level, consumption, and savings in personal finance. This research conducted on 6 villages on Madura as Salt Island, namely Pangarengan and Ragung in Sampang City, Dasuk and Lembung in Pamekasan city, Karanganyar and Pinggirpapas in Sumenep city. 130 respondents was used on this study with purposive sampling technique and descriptive quantitative as a research method. The results show the factors such as: dry season duration, production, farmer categories, productivity levels, salt prices, profit-sharing system, and side job have effect on income levels. Furthermore, that Madura salt farmers prioritize primary consumption with simple financial management. Besides, Madura salt farm also have savings with various pattern and type. They have gold (Jewelry) investment as the main choice.
\end{abstract}

Keywords : Level Income, Consumption, Saving, Personal Finance

\section{PENDAHULUAN}

Manajemen keuangan merupakan salah satu bidang fungsional yang pada dasarnya mempelajari bagaimana memperoleh dana, mengelolah dana dan membagi keuntungan. Belakangan ini, ilmu manajemen keuangan tidak hanya diterapkan dalam perusahaan tetapi rumah tangga juga menerapkan manajemen keuangan. Rumah tangga yang didalamnya ada suami, istri, dan anak merupakan unit keuangan yang terkecil. Pada umumnya diawal pernikahan, sering mengalami kesulitan dalam mengatur keuangan keluarga karena pengelolaan keuangan keluarga belum tertata dengan baik dan belum ada perencanaan komprehensif. Kualitas hidup yang baik itu membutuhkan kondisi keuangan yang sehat, dan kondisi keuangan yang sehat dapat dicapai dengan perencanaan keuangan yang tepat.

Ilmu yang mempelajari cara pengelolaan sumber keuangan individu/ rumah tangga disebut manajemen keuangan pribadi (personal finance). Di Indonesia personal finance mulai berkembang awal tahun 2000, alasan yang mendasari personal finance di Indonesia mengalami perkembangan cukup pesat yaitu: a) Perubahan 
demografi (gaya hidup, perubahan populasi dari segi umur dan gender), b) Perpindahan tanggung jawab pensiun dari Negara/perusahaan ke individual, c) Kecenderungan menurunnya ikatan sosial antar anggota keluarga, seperti dukungan bagi orang tua yang telah jompo dari anaknya, d) Produk keuangan semakin beragam, kompleks dan canggih.

Setiap individu bekerja untuk memperoleh penghasilan/pendapatan. Pendapatan yang diperoleh seseorang merupakan sumber daya yang dapat dikonsumsi pada saat ini atau masa yang akan datang. Pendapatan seseorang biasanya digunakan untuk konsumsi, jika ada sisa digunakan untuk menabung dan investasi. Seseorang yang ingin menabung, akan mengorbankan konsumsi saat ini (sacrifice current consumption). Setiap keluarga seharusnya membuat keputusan seperti berapa banyak pendapatan saat ini yang dikeluarkan untuk dikonsumsi dan berapa banyak seharusnya ditabung menurut preferensinya.

Tingkat pendapatan yang diperoleh akan mempengaruhi tingkat pengeluaran rumah tangga yaitu konsumsi barang dan jasa. Menurut Keynes, pengeluaran konsumsi rumah tangga sangat dipengaruhi oleh besarnya pendapatan yang diterima (Karya, Detri. 2016). Hubungan tingkat pendapatan dan tingkat pengeluaran konsumsi dan tabungan erat kaitannya dengan perencanaan keuangan keluarga. Menurut Joko (2012), jika dalam kehidupan seseorang memberi proporsi pembiayaan untuk investasi, proteksi, perencanaan hari tua dan distribusi kekayaan, maka dapat diindikasikan perencanaan keuangan keluarga telah dilakukan.

Masyarakat perkotaan sudah banyak yang mengenal dan melakukan perencanaan keuangan dengan melakukan investasi pada aset riil maupun aset financial. Tetapi bagaimana dengan masyarakat di pedesaan, bagaimana dengan masyarakat yang pendapatannya harian dan bagaimana dengan masyarakat yang pendapatannya bersifat musiman seperti petani garam.

Diketahui bahwa garam merupakan komoditi strategis sebagai bahan baku industri dan bahan pangan yang sangat dibutuhkan oleh masyarakat. Akan tetapi, kondisi kehidupan petani garam secara umum masih jauh dari ukuran sejahtera. Keadaan petani garam sebagaimana kehidupan pada masyarakat pesisir umumnya menghadapi berbagai permasalahan yang menyebabkan kemiskinan. Mereka menggantungkan hidupnya dari pemanfaatan sumberdaya laut dan sangat bergantung pada iklim. Iklim dan cuaca yang seringkali 
berubah, akan mengakibatkan petani garam gagal melakukan panen, selain itu harga garam di pasar tidak berpihak pada petani. Pendapatan petani garam dipengaruhi oleh tingkat produktivitas (Hayyi, 2015).

Sebagian besar petani garam hanya mengandalkan pendapatan dari produksi garam di musim kemarau (Nugroho, 2018). Ketika musim hujan mereka akan memperbaiki lahan atau tambak garam, untuk menyambung hidup banyak dari mereka yang berhutang dan terkadang menjual barang-barang berharga seperti perhiasan.

Berdasarkan ulasan di atas, peneliti tertarik untuk mengetahui personal finance petani garam dengan mengamati tingkat pendapatan dan tingkat pengeluaran konsumsi serta pola menabung yang dilakukan mereka. Hal ini menjadi menarik karena pendapatan petani garam bersifat musiman dan bergantung pada musim produksi, ketika musim produksi memiliki panas panjang maka tingkat pendapatan tinggi. Selain itu, pendapatan dipengaruhi oleh hasil produksi dan harga pasar. Tingkat pendapatan petani garam bervariasi tergantung pada kategori. Pada kategori petani pekerja yaitu pendapatan pemborong/penggarap berdasarkan sistem bagi hasil, pendapatan buruh pengolok yaitu upah harian, buruh angkut pendapatannya per karung, sedangkan buruh mandor bayarannya setiap panin.

Setiap keluarga memiliki cara sendiri dalam mengatur keuangan keluarga. Tingkat pendapatan akan mempengaruhi pola konsumsi dan menabung setiap keluarga. Pendapatan petani garam bersifat musiman, oleh karena itu mereka harus mampu merencanakan keuangan keluarga secara cermat. Penelitian ini bertujuan untuk mengetahui dan mengkaji tingkat pendapatan, pola konsumsi dan pola menabung petani garam dalam personal finance.

Personal finance berarti melakukan proses perencanaan keuangan untuk memenuhi kebutuhan keuangan pribadi dan keluarganya. Konsep ini memerlukan proses perencanaan yang terkoordinasi dan berkelanjutan disesuaikan tujuan keuangan individu. Perencanaan keuangan individu dikelompokan menjadi dua yaitu: a) Perencanaan keuangan menyeluruh (comprehensive financial planning) yang mencakup semua kebutuhan keuangan seseorang, termasuk manajemen risiko dan perencanaan asuransi, perencanaan investasi, perencanaan pajak, perencanaan hari tua serta perencanaan distribusi kekayaan; b) Perencanaan keuangan untuk kebutuhan khusus 
(special need planning) adalah perencanaan keuangan yang terfokus pada satu kebutuhan saja seperti perencanaan pendidikan anak dari TK sampai perguruan tinggi, perencanaan membeli rumah, perencanaan membeli mobil, dan lain-lain.

\section{METODE}

Penelitian ini dilakukan dengan pendekatan kuantitatif deskriptif. Metode ini dipilih dengan tujuan untuk mendeskripsikan dan menggambarkan data secara mendalam tanpa melakukan uji statistik. Dari hasil yang diperoleh akan diketahui pola konsumsi dan pola menabung masyarakat dalam merencanakan keuangan keluarga.

Penelitian ini dilakukan di daerah penghasil garam di tiga kabupaten yaitu Kabupaten Sampang, Pamekasan dan Sumenep. Responden yang menjadi sumber data dari penelitian ini adalah petani garam. Penarikan sampel akan dilakukan dengan menggunakan teknik Non probability sampling yaitu sampling purposive, dimana dalam teknik ini pengambilan sampel dilakukan dengan pertimbangan tertentu. Seperti, responden harus bisa menulis dan membaca, responden adalah kepala rumah tangga dan lebih 5 tahun berkeluarga.

Variabel dalam penelitian ini adalah (1) tingkat pendapatan yaitu besarnya pendapatan yang diperoleh petani garam. Indikator pendapatan antara lain, besarnya pendapatan setiap musim; pekerjaan sampingan selain petani garam; sumber pendapatan lainnya. (2) Konsumsi adalah tindakan pelaku ekonomi yaitu keluarga dalam menggunakan komunitas baik barang maupun jasa untuk memenuhi kebutuhannya. Indikator pola konsumsi antara lain, biaya untuk makan keluarga; sandang; biaya pendidikan anak; biaya listrik; biaya PDAM; biaya komunikasi; biaya transportasi; biaya lain-lain. (3) Tabungan adalah simpanan berupa uang yang dimiliki oleh petani garam. Indikator pola tabungan yaitu besarnya jumlah tabungan; bentuk tabungan; jangka waktu menabung; konsistensi menabung.

Data diperoleh dengan cara menyebarkan kusioner kepada petani garam dan melakukan wawancara terstruktur dengan pihak-pihak yang dianggap mempunyai pengetahuan dan pemahaman atas permasalahan dalam penelitian ini.

\section{HASIL PENELITIAN}

Responden dalam penelitian ini sebanyak 130 orang petani garam yang tersebar di enam desa yaitu Desa Pangarengan dan Ragung Kabupaten Sampang, Desa Dasuk dan Lembung di Kabupaten Pamekasan dan di Kabupaten Sumenep ada Desa Karanganyar dan Pinggirpapas. Responden penelitian ini 
semuanya adalah laki-laki, karena salah satu pertimbangan dalam penelitian ini yaitu responden merupakan kepala keluarga. Penelitian ini mengkaji karakteristik responden yang meliputi kategori petani garam, umur responden, tingkat pendidikan, pengalaman kerja, jumlah tanggungan keluarga, pendapatan per musim dan sumber pendapatan lainnya.

\section{Kategori petani garam}

Petani garam dibedakan menjadi dua jenis yaitu petani pemilik dan petani buruh. Petani pemilik yaitu mereka yang memiliki hak milik dan penguasaan atas lahan yang digunakan untuk memproduksi garam, selain sebagai pemilik lahan mereka juga bekerja untuk memproduksi garam. Sedangkan petani buruh adalah petani garam yang tidak memiliki lahan, tapi hanya menggarap atau menjual jasa tenaga kerja yang bekerja untuk membuat garam krosok pada pemilik lahan. Petani buruh/pekerja dibagi lagi berdasarkan jenis pekerjaannya yaitu ada petani pemborong/penggarap, petani pengolok, petani angkut dan mandor. Petani pemborong atau penggarap yaitu orang yang mengerjakan atau menggarap lahan orang lain dengan sistem bagi hasil. Petani pengolok adalah petani yang bekerja jika diminta dan bayarannya dihitung per hari. Petani angkut yaitu mereka yang bekerja mengangkut garam dari lahan garam ke gudang atau ke jalan, bayarannya per karung. Mandor adalah mereka yang mengawasi lahan garam milik orang yang dikerjakan oleh petani. Hasilnya menunjukkan 101 responden adalah petani pekerja dan petani pemilik sebanyak 29 orang.

\section{Umur responden}

Umur merupakan faktor penentu dalam mencapai keberhasilan dalam suatu kegiatan usaha. Umur yang masih produktif akan lebih cepat dalam bekerja. Kisaran umur responden adalah antara 25-85 tahun. Berdasarkan hasil penelitian menunjukkan bahwa umur petani garam termasuk kategori produktif dan tidak produktif. Dimana $11 \%$ responden berusia antara $26-35$ tahun, kisaran umur petani 36 - 45 tahun $29 \%$, kisaran umur 46 - 55 tahun sebesar $37 \%$, kisaran umur 56 - 65 tahun yaitu 19\%, kisaran umur 66 - 75 tahun adalah $3 \%$ dan kisaran umur 76 - 85 tahun adalah $1 \%$. Umur responden paling tua yaitu 80 tahun dan paling muda 29 tahun. Bekerja menjadi petani garam yang dibutuhkan hanya tenaga sedangkan pengetahuan terkait suhu air, ketinggian air dan kapan garam dipanen diperoleh dari pengalaman. Semakin lama mereka berkerja semakin menguasai tentang garam.

\section{Tingkat pendidikan}

Tingkat pendidikan diukur berdasarkan pendidikan formal terakhir yang pernah 


\section{FAKULTAS EKONOMI DAN BISNIS UNIVERSITAS WIRARAJA - MADURA}

diperoleh dan diselesaikan oleh responden. Tingkat pendidikan petani garam sebagian besar adalah tamat/tidak sekolah dasar (SD) yaitu $61 \%$, petani yang tidak sekolah berjumlah $4 \%$, petani tamat sekolah tingkat pertama (SMP) sebanyak $20 \%$, petani tamat sekolah tingkat akhir (SMA) berjumlah $14 \%$, sedangkan petani lulusan sarjana hanya $1 \%$. Responden menyampaikan, proses pembuatan garam tidak pernah diajarkan dalam pendidikan formal, sehingga tinggu rendahnya pendidikan formal tidak memberikan pengaruh besar terhadap pekerjaan mereka. Pendidikan formal memberi ilmu pengetahuan secara umum tidak spesifik mengenai ilmu tentang garam, sehingga banyak petani garam yang meremehkan pentingnya pendidikan.

\section{Pengalaman kerja}

Pengalaman kerja berkaitan dengan lama responden menjadi petani garam yang dihitung dalam satuan waktu (tahun), sejak pertama kali menjadi petani garam sampai dengan penelitian dilakukan. Pengalaman responden sebagai petani garam dilokasi penelitian cukup bervariasi, ada yang baru memulai selama 1 tahun, namun ada juga yang sudah memiliki pengalaman lebih dari 20 tahun. Responden yang memiliki pengalaman lebih dari 20 tahun bekerja sebagai petani garam sebanyak 60 orang, sebesar $20 \%$ responden bekerja sebagai petani garam selama 16 - 20 tahun, petani yang bekerja selama 11 - 15 tahun berjumlah $15 \%$, responden dengan pengalaman bekerja sebagai petani garam $6-10$ tahun ada $14 \%$ dan hanya $5 \%$ atau 6 orang yang baru memiliki pengalaman bekerja selama 1 - 5 tahun. Pada pembuatan garam, petani tidak membutuhkan pengetahuana khusus. Semakin lama mereka bekerja semakin menguasai proses pembuatan garam.

\section{Jumlah Tanggungan Keluarga}

Jumlah tanggungan keluarga sangat berpengaruh terhadap tingkat kesejahteraan keluarga, jumlah tanggungan keluarga yang sedikit tingkat kesejahteraannya akan lebih tinggi/baik bila dibandingkan dengan jumlah anggota keluarga yang lebih banyak. Jumlah tanggungan keluarga responden cukup beragam mulai dari 1 orang sampai dengan 8 orang. Tanggungan keluarga petani garam yaitu istri, anak, dan orang tua.

Pekerjaan Lainnya (Pekerjaan Sampingan)

Hasil penelitian menunjukkan bahwa lima puluh satu persen (51\%) petani garam tidak memiliki pekerjaan lain. Sebagian besar mereka bekerja hanya sebagai petani garam dan tidak memiliki pekerjaan lain atau sampingan. Sisanya empat puluh sembilan persen $(49 \%)$ petani garam memiliki pekerjaan 


\section{FAKULTAS EKONOMI DAN BISNIS UNIVERSITAS WIRARAJA - MADURA}

sampinga yaitu ada yang bekerja menjadi petani di sawah, kuli bangunan, pedagang, pekerja serabutan, kuli pasir, nelayan, guru ngaji dan beternak. Bagi petani yang tidak memiliki pekerjaan lain, pada musim hujan mereka tidak bekerja.

\section{Tingkat Pendapatan Petani Garam}

Pendapatan petani garam setiap musim berkisar antara Rp. 5.000.000,- sampai dengan Rp. 60.000.000,-. Sebaran pendapatan responden per musim dapat dilihat pada tabel 1. Berdasarkan hasil penelitian diketahui bahwa sebagian besar petani garam memiliki pendapatan per musim berkisar antara Rp. 30.000.000,- sd Rp. 40.000.000,- Petani garam yang memiliki pendapatan lebih dari Rp. 60.000.000,- setiap musim sebanyak 5\%. Sembilan belas persen (19\%) petani garam memiliki pendapatan kurang dari Rp. 10.000.000,setiap musimnya.

Petani garam yang pendapatan setiap musimnya lebih dari Rp. 40.000.000,adalah mereka yang memiliki lahan sendiri dan dikerjakan sendiri. Mereka yang memiliki pendapatan setiap musim berkisar antara Rp. 10.000.000,- sampai dengan Rp. 40.000.000,- adalah petani yang menggarap lahan orang lain. Petani yang menggarap lahan orang lain pendapatannya berdasarkan sistem bagi hasil. Menurut (Ghani dan Singgi, 2019), sistem bagi hasil merupakan salah satu faktor penentu tingkat pendapatan pemilik lahan dan petani penggarap pada usaha garam. Petani dengan pendapatan setiap musim berkisar antara Rp. 5.000.000,- sampai Rp. 10.000.000,- adalah petani pangolok, petani angkut dan mandor.

Tabel 1

Pendapatan Petani per Musim

\begin{tabular}{|c|l|c|c|}
\hline No & \multicolumn{1}{|c|}{ Kategori } & Jumlah & Persentase \\
\hline 1 & Rp. 5.000.000,- sd Rp. 10.000.000,- & 25 & $19 \%$ \\
\hline 2 & > Rp. 10.000.000,- sd Rp. 20.000.000,- & 20 & $15 \%$ \\
\hline 3 & > Rp. 20.000.000,- sd Rp. 30.0000.000,- & 17 & $13 \%$ \\
\hline 4 & > Rp. 30.000.000,- sd Rp. 40.000.000,- & 40 & $31 \%$ \\
\hline 5 & > Rp. 40.000.000,- sd Rp. 50.000.000,- & 14 & $11 \%$ \\
\hline 6 & > Rp. 50.000.000,- sd Rp. 60.000.000,- & 8 & $6 \%$ \\
\hline 7 & > Rp. 60.000.000,- & 6 & $5 \%$ \\
\hline \multicolumn{2}{|l|}{ Total } & $\mathbf{1 3 0}$ & $\mathbf{1 0 0 \%}$ \\
\hline
\end{tabular}

Sumber : data diolah peneliti

Pendapatan petani garam bersifat bergantung pada kondisi alam. Kegiatan musiman, pekerjaan mereka sangat produksi garam pada umumnya 
dilakukan pada musim kemarau yaitu mulai bulan Mei sampai November atau pertengahan Desember, dengan musim puncak produksi garam terjadi pada bulan September - Oktober. Jumlah produksi dan harga garam adalah faktor yang mempengaruhi tingkat pendapatan petani garam. Jumlah garam yang dihasilkan akan menentukan tingkat pendapatan, semakin banyak garam yang diproduksi maka semakin besar pendapatan yang diperoleh begitu juga sebaliknya. Harga garam juga menentukan besar kecilnya pendapatan petani garam, jika harga garam tinggi maka pendapatan petani akan lebih banyak dan sebaliknya jika harga garam rendah. Berdasarkan hasil penelitian (Nugroho, 2018) dijelaskan bahwa permasalahan yang sering dihadapi petani adalah harga garam yang tidak stabil. Harga garam di pasar tergantung pada kualitas dan kuantitas garam. Berdasarkan kualitas, garam dikelompokkan menjadi tiga kelompok yaitu garam kualitas 1 , kualitas 2 dan kualitas 3. Garam dengan kualitas 1 memiliki harga paling tinggi dan garam kualitas 3 memiliki harga paling rendah.
Seperti pada hukum permintaan dan penawaran, ketika penawaran di pasar banyak maka harga garam akan turun begitu juga sebaliknya.

Sebagian besar petani garam di Madura tidak memiliki pekerjaan sampingan (pekerjaan lain). Bekerja sebagai petani garam menjadi mata pencaharian utama pada musim kemarau. Akan tetapi, ada beberapa dari mereka yang memiliki pekerjaan sampingan. Mereka yang bekerja hanya sebagai buruh pengolok dan buruh angkut biasanya memiliki pekerjaan sampingan karena mereka bekerja jika diminta untuk bekerja. Pekerjaan sampingan ini akan menjadi sumber pendapatan lainnya selain menjadi petani garam.

\section{Sumber Pendapatan Lainnya Petani}

\section{Garam}

Berdasarkan hasil penelitian diketahui bahwa sebagian besar keluarga petani garam $(51 \%)$ pendapatannya hanya bersumber dari garam. Empat puluh sembilan persen (49\%) petani garam memiliki sumber pendapatan lain yaitu berasal dari pendapatan istri yang bekerja, pemberian dari anak, dan lainnya.

Tabel 2

Besarnya Pendapatan Lainnya

\begin{tabular}{|c|c|c|}
\hline No & Besaran pendapatan lainnya & Jumlah \\
\hline
\end{tabular}




\begin{tabular}{|c|l|c|}
1 & 0 & 66 \\
\hline 2 & $\leq$ Rp. $500.000,-$ & 12 \\
\hline 3 & $>$ Rp. $500.000,-$ sd Rp. $1.000 .000,-$ & 27 \\
\hline 4 & $>$ Rp. $1.000 .000,-$ sd Rp. $2.000 .000,-$ & 15 \\
\hline 5 & $>$ Rp. 2.000.000,- sd Rp. 3.000.000,- & 6 \\
\hline 6 & $>$ Rp. 3.000.000,- & 4 \\
\hline \multicolumn{2}{|l|}{ Total } & $\mathbf{1 3 0}$ \\
\hline
\end{tabular}

Sumber : data diolah peneliti

Tabel 2 menunjukkan besarnya pendapatan petani garam dari sumber lain. Pendapatan ini berasal dari istri yang bekerja, pemberian anak dan lainnya. Pendapatan petani garam dari sumber lainnya berkisar antara $\leq \mathrm{Rp}$. 500.000,- sd > Rp. 3.000.000,-. Hanya tiga persen $(3 \%)$ petani garam yang memiliki pendapatan dari sumber lain lebih dari Rp. 3.000.000,- setiap bulan, sedangkan petani yang memiliki pendapatan tambahan dari sumber lain kurang atau sama dengan Rp. 500.000,sebanyak 9\%. Rata-rata petani memiliki tambahan penghasilan dari sumber lain setiap bulannya berkisar antara > Rp. 500.000,- sd Rp. 1.000.000,-.

\section{Pola Konsumsi Petani Garam}

Secara umum pengeluaran konsumsi rumah tangga dibagi menjadi tiga kelompok yaitu pengeluaran pangan, sandang dan papan. Umumnya besarnya tingkat pengeluaran bervariasi tergantung besarnya tingkat pendapatan masing- masing rumah tangga petani garam. Tingkat pendapatan akan berpengaruh terhadap pola konsumsi masyarakat. Menurut Keynes, pengeluaran konsumsi rumah tangga sangat dipengaruhi oleh besarnya pendapatan. Semakin tinggi pendapatan makan semakin besar konsumsi begitu juga sebaliknya. Perbandingan antara besarnya perubahan pengeluaran konsumen rumah tangga dan perubahan pendapatan disebut hasrat atau keinginan dari rumah tangga tersebut dalam berkonsumsi, besarnya hasrat ini disebut hasrat marjinal berkonsumsi.

Pola konsumsi yang dikeluarkan oleh petani garam pada penelitian ini terbagi atas beberapa kategori yaitu: konsumsi (makanan dan pakaian), biaya pendidikan, konsumsi listrik, PDAM, kesehatan, komunikasi, transportasi, kredit (cicilan hutang), dan lainnya. Setiap keluarga memiliki pola konsumsi yang berbeda, karena setiap rumah tangga memiliki kebutuhan yang berbeda.

Apabila pendapatannya rendah akan lebih mengutamakan kebutuhan pengeluaran pokok yaitu bahan makanan, sebaliknya apabila pendapatan yang dihasilkan tinggi akan terjadi pergeseran antara kebutuhan makanan dengan kebutuhan bukan makanan. 
Pengeluaran rumah tangga petani garam di Madura antara lain:

Pola pengeluaran bahan makanan (konsumsi) rumah tangga petani garam di Madura dilihat rata-rata pengeluaran untuk konsumsi selama satu bulan. Dari hasil penelitian menunjukkan bahwa rata-rata pengeluaran petani garam untuk makan satu bulan berkisar antara Rp. 1.000 .000 - Rp. 2.000.000,-. Pengeluaran ini digunakan untuk membeli beras, ikan, bumbu-bumbu, sayuran, minuman dan kebutuhan makan lainnya. Hanya dua persen $(2 \%)$ petani garam yang pengeluaran konsumsinya satu bulan berkisar antara lebih dari Rp. 3.000.0000,- sampai Rp. 4.000.000,-. Sebanyak sepuluh persen (10\%) keluarga petani garam memiliki pengeluaran konsumsi setiap bulan kurang dari Rp. 500.000,--.

Kesadaran masyarakat akan pendidikan semakin meningkat, begitu juga dengan petani garam. Besarnya biaya pendidikan yang dikeluarkan oleh petani garam cukup bervariasi yaitu bekisar kurang dari Rp. 500.000,- sampai Rp. 3.000.000,- per bulan. Pengeluaran biaya pendidikan ini hanya terbatas pada biaya pembelian buku, tas sekolah, sepatu dan uang jajan, sedangkan untuk biaya sumbangan pendidikan (SPP) sudah gratis untuk tingkat sekolah dasar. Ada beberapa anak petani garam yang melanjutkan ke bangku kuliah, biasanya mereka menyisihkan uang setiap bulannya untuk membayar biaya per semester. Dari hasil penelitian diketahui bahwa sebanyak tiga puluh tiga persen (33\%) petani garam tidak memiliki tanggungan biaya pendidikan, hal ini terjadi karena anak-anak mereka sudah berkeluarga dan ada diantara mereka yang tidak memiliki anak. Pengeluaran pendidikan tertinggi yang harus dikeluarkan petani garam setiap bulan adalah Rp. 3.000.000,- , akan tetapi hanya empat persen $(4 \%)$ petani garam yang memiliki pengeluaran pendidikan berkisar antara Rp. 2.000.000,- sampai Rp. 3.000.000,-. Rata-rata biaya pendidikan yang dikeluarkan petani garam setiap bulan berkisar antara Rp. 500.000,- Rp. 1.000.000,-.

Pengeluaran petani garam untuk biaya listrik relatif rendah. Pengeluaran biaya listrik rata-rata satu bulan berkisar antara Rp. 50.000,- sampai Rp. 100.000,-Jika dilihat dari biaya listrik yang dikeluarkan, pemakaian listrik hanya untuk lampu, televisi dan lemari es (kulkas). Daya listrik setiap rumah ratarata $450 \mathrm{Kwh}$ dan mendapatkan subsidi dari pemerintah sehingga pengeluaran biaya listrik tidak terlalu mahal.

Air merupakan salah satu kebutuhan rumah tangga yang sangat utama. Air yang digunakan sehari-hari untuk kebutuhan rumah tangga sebagian besar diperoleh melaui jaringan PDAM 
(Perusahaan Daerah Air Minum), ini karena air di sana (daerah lahan garam) rasanya payau dan ada pula yang asin. Besarnya pengeluaran untuk biaya PDAM rata-rata satu bulan berkisar antara Rp. 50.000,- sampai Rp. 100.000,-. Dari data yang diperoleh diketahui bahwa dua puluh lima persen (25\%) petani garam tidak ada pengeluaran untuk PDAM.

Pengeluaran untuk biaya kesehatan setiap bulan rata-rata berkisar antara Rp. 50.000,- sampai Rp. 100.000,-. Jika dilihat biaya kesehatan yang dikeluarkan bukan untuk penyakit yang berat dan serius melainkan biaya kesehatan untuk penyakit yang umum dan biasa terjadi. Berdasarkan hasil wawancara, biaya kesehatan ini seperti membeli jamu dan obat-obatan. Sebagian besar petani garam yaitu delapan puluh satu persen (81\%) tidak mempunyai pengeluaran untuk kesehatan, ketika sakit mereka akan berobat ke puskesmas atau ke rumah sakit secara gratis dengan Kartu Indonesia Sehat (KIS).

Biaya pengeluaran petani garam untuk komunikasi cukup rendah dibandingkan dengan pengeluaran untuk biaya lainnya. Hasil penelitian menunjukkan bahwa rata-rata kisaran pengeluaran petani garam untuk biaya komunikasi yaitu Rp. 25.000,- sampai 50.000,-

Pengeluaran transportasi petani garam setiap bulan relatif kecil. Hal ini disebabkan karena ruang lingkup rumah tangga petani garam hanya sekitaran tambak dan rumah. Hasil penelitian menunjukkan bahwa sebagian besar petani garam mengeluarkan biaya untuk transportasi berkisar lebih dari Rp. 100.000,- sampai Rp. 150.000,- setiap bulan. Petani garam dalam melakukan kegiatan sehari-hari lebih memilih untuk naik sepeda mini (sepeda engkol). Petani garam yang pekerjaannya sebagai buruh angkut (petani angkot) mempunyai pengeluaran biaya transportasi lebih besar yaitu untuk pembelian bahan bakar (bensin) sepeda motor.

Sebagian besar petani garam tidak memiliki kredit atau cicilan hutang yaitu delapan puluh persen (80\%). Mayoritas kredit yang dibayarkan adalah kredit kendaraan (sepeda motor), pinjaman ke perbankan untuk modal usaha garam, serta cicilan untuk keperluan rumah tangga. Besarnya pengeluaran kredit atau cicilan pinjaman setiap bulan dapat dilihat pada tabel 3 berikut.

Pengeluaran untuk biaya lain-lain atara lain biaya sosial, biaya adat dan lainnya yang tidak dimasukkan dalam kelompok pengeluaran di atas. Rata-rata pengeluaran petani garam untuk ini berkisar antara Rp. 100.000 sampai Rp. 200.000,- per bulan.

Total pengeluaran bukan makanan petani garam cukup tinggi setiap bulannya. Pengeluaran bukan makanan 
FAKULTAS EKONOMI DAN BISNIS UNIVERSITAS WIRARAJA - MADURA

setiap bulannya lebih besar konsumsi petani garam setiap bulan dibandingkan dengan pengeluaran bahan ditunjukkan pada tabel 3.

makanan. Rata-rata pengeluaran

Tabel 3

Pengeluaran Konsumsi Petani Garam

\begin{tabular}{|c|l|r|r|}
\hline No & \multicolumn{1}{|c|}{ Jenis Pengeluaran } & $\begin{array}{c}\text { Kisaran Terendah } \\
(\mathbf{R p})\end{array}$ & $\begin{array}{c}\text { Kisaran Tertinggi } \\
(\mathbf{R p})\end{array}$ \\
\hline 1. & Konsumsi makanan & $1.000 .000,-$ & $2.000 .000,-$ \\
\hline 2. & Pendidikan & $500.000,-$ & $1.000 .000,-$ \\
\hline 3. & Biaya Listrik & $50.000,-$ & $100.000,-$ \\
\hline 4. & PDAM & $50.000,-$ & $100.000,-$ \\
\hline 5. & Kesehatan & $50.000,-$ & $100.000,-$ \\
\hline 6. & Komunikasi & $25.000,-$ & $50.000,-$ \\
\hline 7. & Transportasi & $100.000,-$ & $150.000,-$ \\
\hline 8. & Kredit & $0,-$ & $500.000,-$ \\
\hline 9. & Lainnya & $100.000,-$ & $200.000,-$ \\
\hline Total & & $\mathbf{1 . 8 7 5 . 0 0 0 , -}$ & $\mathbf{4 . 2 5 0 . 0 0 0 , -}$ \\
\hline
\end{tabular}

Sumber : data diolah peneliti

Berdasarkan hasil penelitian non ekonomi. Pada penelitian ini, faktor menunjukkan bahwa pola konsumsi petani garam di Madura dikelompokkan menjadi dua yaitu pengeluaran konsumsi (makanan dan pakaian), pengeluaran bukan makan antara lain biaya pendidikan, listrik, PDAM, kesehatan, komunikasi, transportasi, kredit dan lainnya. Pola pengeluaran makanan rumah tangga petani garam per bulan relatif sama besarnya dengan pengeluaran bukan makanan. Pada pola pengeluaran bukan makanan, ada pengeluaran lainnya yaitu ada biaya adat dan biaya tengka yang memiliki porsi pengeluaran cukup besar setiap bulannya selain pendidikan.

Faktor yang mempengaruhi konsumsi rumah tangga, antara lain faktor ekonomi, faktor demografi, dan faktor non-ekonomi yang paling berpengaruh terhadap besarnya konsumsi petani garam yaitu faktor sosial budaya masyarakat.

\section{Pola Menabung Petani Garam}

Menabung artinya manyisihkan sebagian pendapatan atau penghasilan yang diperoleh untuk digunakan dimasa yang akan datang. Menabung adalah keputusan menunda konsumsi sekarang. Sebesar delapan puluh delapan persen (88\%) responden memiliki tabungan dan sisanya dua belas persen (12\%) tidak memiliki tabungan. Hasil penelitian menjelaskan tujuan petani garam menabung adalah untuk berjaga-jaga adanya kebutuhan mendadak, untuk kebutuhan pendidikan anak, untuk biaya penikahan anak, untuk biaya kesehatan 
anggota keluarga dikhawatirkan ada yang sakit dan untuk kebutuhan biaya hidup ketika musim hujan.

Bentuk tabungan yang dipilih bermacam-macam, ada yang menabung dalam bentuk uang tunai di rumah, simpanan di bank, arisan dan deposito serta ada petani yang menabung lebih dari satu bentuk tabungan. Tabel 4 menunjukkan bentuk tabungan yang banyak dipilih petani garam. Hasil penelitian menunjukkan bahwa sebagian besar petani memilih bentuk tabungan berupa uang tunai yang disimpan di rumah, alasanya adalah lebih praktis dan lebih mudah di ambil jika ada kepentingan mendadak dan mendesak. Arisan juga merupakan salah satu bentuk tabungan yang sangat diminati oleh petani garam.

Tabel 4

Bentuk Tabungan Petani Garam

\begin{tabular}{|c|l|c|c|}
\hline No. & \multicolumn{1}{|c|}{ Bentuk Tabungan } & Jumlah & $\begin{array}{c}\text { Persentase } \\
(\%)\end{array}$ \\
\hline 1 & Uang Tunai & 34 & 26,15 \\
\hline 2 & Simpanan di bank dan uang tunai & 26 & 20, \\
\hline 3 & Arisan & 25 & 19,23 \\
\hline 4 & Tidak Ada & 15 & 11,54 \\
\hline 5 & Uang tunai dan arisan & 13 & 10, \\
\hline 6 & Simpanan di bank dan arisan & 7 & 5,38 \\
\hline 7 & Simpanan di Bank & 3 & 4,62 \\
\hline 8 & Simpanan di bank, uang tunai, dan arisan & 1 & 2,31 \\
\hline 9 & Deposito dan arisan & $\mathbf{1 3 0}$ & $\mathbf{1 0 0}$ \\
\hline Total & & & 0,77 \\
\hline
\end{tabular}

Sumber : data diolah peneliti

Gambar 1

Periode Menabung Petani Garam 


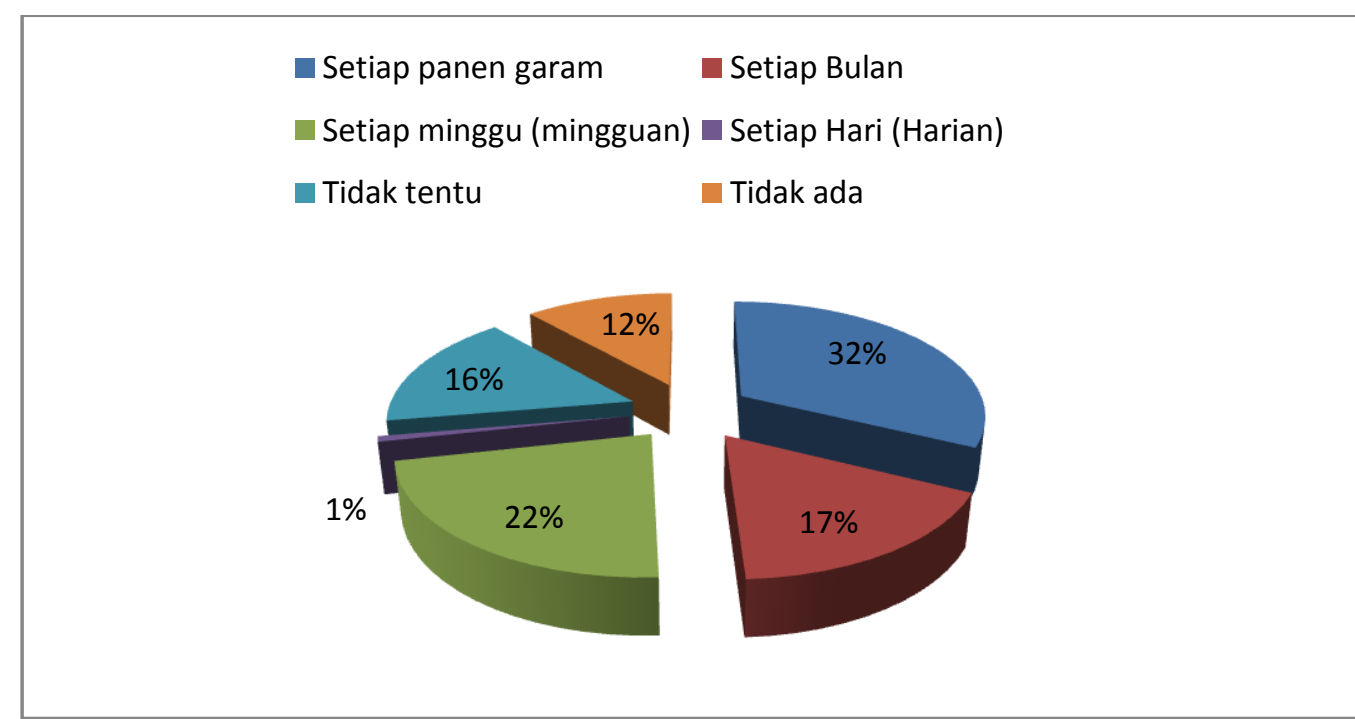

Sumber: data diolah peneliti

Periode menabung petani juga bulanan. Gambar 1 menunjukkan bervariasi, ada yang menabung setiap persentase periode menabung petani panen, setiap bulan, setiap minggu garam.

(mingguan), setiap hari (harian), dan ada

Besarnya tabungan petani garam yang tidak tentu pola menabungnya. berkisar antara kurang dari Rp. Sebagian besar petani garam menabung 500.000,- sampai lebih Rp. 5.000.000,-. pada saat panen. Petani garam dengan Rata-rata tabungan petani kurang dari periode menabung setiap minggu sebanyak dua puluh dua persen (22\%), dan tujuh belas persen (17\%) petani garam menabung dengan periode Rp. 500.000,-Jumlah tabungan petani garam bervariasi, ini teragntung dari pendapatan mereka setiap musim dan besarnya pengeluaran.

Tabel 5

Jumlah Tabungan Petani Garam

\begin{tabular}{|c|l|c|c|}
\hline No & \multicolumn{1}{|c|}{ Jumlah uang yang ditabung } & Jumlah & $\begin{array}{c}\text { Persentase } \\
(\mathbf{\%})\end{array}$ \\
\hline 1 & 0 & 15 & $11 \%$ \\
\hline 2 & < Rp. 500.000,- & 48 & $37 \%$ \\
\hline 3 & $\geq$ Rp. 500.000,- sd Rp. 1.000.000,- & 16 & $12 \%$ \\
\hline 4 & > Rp. 1000.000,- sd Rp. 2.000.000,- & 10 & $8 \%$ \\
\hline 5 & > Rp. 2000.000,- sd Rp. 3.000.000,- & 2 & $2 \%$ \\
\hline 6 & > Rp. 3.000.000,- sd Rp. 5.000.000,- & 7 & $5 \%$ \\
\hline 7 & > Rp. 5.000.000 & 23 & $18 \%$ \\
\hline 8 & Tidak Menentu & 9 & $7 \%$ \\
\hline Total & $\mathbf{1 3 0}$ & $\mathbf{1 0 0 \%}$ \\
\hline
\end{tabular}

Sumber : data diolah peneliti 
Petani garam harus membuat keputusan keuangan seperti berapa banyak pendapatan saat ini yang seharusnya dihabiskan atau konsumsi dan berapa banyak seharusnya ditabung menurut preferensinya. Dalam menetapkan preferensinya, mereka seharusnya membuat keputusan sedemikian rupa sehingga mencapai tingkat tertinggi kepuasan personal. Seseorang dalam membuat keputusan konsumsi/tabunga dalam suatu cara yang akan memaksimalkan utilitasnya. Utilitas merupakan pengukuran tingkat kepuasan individu dan akan berbeda-beda antar individu.

Temuan lain di lapangan yaitu ternyata selain menabung, sebagian besar petani garam di Madura memiliki investasi pada aset riil. Investasi adalah suatu komitmen atas sejumlah dana atau sumber daya lainnya yang dilakukan pada saat ini dengan tujuan memperoleh sejumlah keuntungan dimasa yang akan datang. Bentuk investasi dikelompokan menjadi 2 yaitu: real asset dan financial asset. (Tandelilin, 2017). Mayoritas investasi yang dipilih adalah emas (perhiasan) karena menurut mereka harga emas akan terus naik dari waktu ke waktu. Selain itu, emas memiliki sifat likuid yaitu cepat diuangkan. Ternak juga menjadi pilihan investasi petani garam karena harga terjangkau dan bisa dijual ketika mereka butuh uang. Ada beberapa petani garam yang melakukan investasi dengan membeli atau menyewa lahan tambak.

Dalam pengambilan keputusan keuangan, petani garam di Madura lebih mengutamakan kebutuhan konsumsi. Pengeluaran konsumsi (makanan dan pakaian) hampir sama besarnya dengan pengeluaran konsumsi bukan makanan. Sebagain besar petani garam sudah mulai mengelolah (mengatur) keuangan rumah tangga mereka meski sangat sederhana. Mereka tidak membelanjakan semua pendapatan untuk konsumsi saat ini, akan tetapi mereka menyisihkan sebagian penghasilan untuk di tabung. Pola konsumsi dan pola menabung petani garam bergantung pada preferensi masing-masing rumah tangga.

\section{KESIMPULAN DAN SARAN}

Pendapatan petani garam yang bersifat musiman memerlukan perencanaan keuangan yang tepat. Hal tersebut dikarenakan sebagian besar pendapatan yang diperoleh digunakan untuk memenuhi kebutuhan hidup selama setahun. Mayoritas petani garam sudah mulai mengelola keuangan rumah tangga walaupun dengan sangat sederhana. Dalam kesehariannya, kebutuhan konsumsi menjadi pilihan utama dipenuhi oleh petani garam.

Pola konsumsi petani garam di Madura terbagi atas dua pola, diantaranya pengeluaran makan dan 
pakaian dan pengeluaran bukan makan.

Selain untuk konsumsi tersebut, sebagian pendapatan disisihkan untuk tabungan.

Terdapat beberapa bentuk tabungan yang dipilih oleh petani garam Madura, yaitu uang tunai yang disimpan di rumah yang menjadi bentuk tabungan yang paling diminati petani garam Madura. Dalam hal tabungan arisan juga menjadi pilhan petani garam untuk menabung. Ini menjadi temuan yang cukup menarik dalam hal pengelolaan keuangan petani garam Madura.

Berbagai pola dalam periode tabungan juga ditemukan dalam penelitian ini. Petani garam memiliki pola menabung yang bervariasi, mulai dari harian, mingguan, bulanan, hingga setiap musim. Selain tabungan, penelitian ini juga menangkap bahwa petani garam Madura memilih untuk berinvestasi pada emas dibandingkan pilihan lainnya. Lebih lanjut, besarnya konsumsi dan tabungan bergantung pada preferensi dari masing-masing rumah tangga petani garam di Madura.

Penelitian ini memiliki kelemahan diantaranya: dikarenakan penelitian ini dilakukan pada masa pandemi Covid-19, maka ditafsirkan dapat mempengaruhi hasil penelitian. Sehingga, penelitian ini perlu dilakukan dengan sifat longitudinal untuk dapat menggambarkan dengan baik tingkat pendapatan petani garam, pola konsumsi,dan pola tabungan petani garam Madura dalam personal finance.

Untuk penelitian selanjutnya mengenai pengelolaan keuangan petani garam, mungkin perlu lebih memperhatikan gender dari petani garam, dikarenakan perbedaan gender juga sangat menarik jika diangkat menjadi topik penelitian petani garam selanjutnya.

\section{DAFTAR PUSTAKA}

Azizi, Manadiyanto, Sonny Koeshendrajana. 2011. Dinamika Usaha, Pendapatan dan Pola Pengeluaran Konsumsi Petambak Garam Di Desa Pinggirpapas Kecamatan Kalianget Kabupaten Sumenep. J. Sosek KP Vol. 6 No. 2.

Ghani, Echsan, Boy Singgih Gitayuda. 2020. The Income of Salt Farmers in Madura: an Explanation of Profit-Sharing System. Jurnal Media Trend 15 (2).

Joko, Agus. 2012. Pola Konsumsi Pola Investasi Dan Pola Proteksi Sebagai Indikator Perencanaan Keuangan Keluarga. Media Mahardika 10 (2).

Karya, Detri, Syamri Syamsuddin. 2016. Makro ekonomi Pengantar untuk Manajemen. Jakarta: PT. Raja Grafindo Persada.

Nugroho, Prasetyo dkk. 2018. Social Mapping Permasalahan Petani Garam Di Desa Pinggirpapas. Prosiding SNM 5.

Prastowo, Andi. 2011. Memahami Metode-Metode penelitian. Jogjakarta: AR-RUZZ MEDIA. 
Rachman A. 2011. Evaluasi kinerja usaha petani garam rakyat (studi kasus di Kabupaten Bima, Nusa Tenggara Barat). [tesis]. Bogor [ID]: Sekolah Pacasarjana, Institut Pertanian Bogor.

Tandelilin, Eduardus. 2017. Pasar Modal Manajemen Investasi dan Portofolio. Jogjakarta: YKPM.
Zainuri, Achmad. 2012. Laporan Pendataan Potensi Garam Jawa Timur. Malang: PPKE.

https://www.isw.co.id/post/2019/07/01/1 0-daerah-penghasil-garam-terbesar-diindonesia 